\title{
Spontaneous and Beta-Adrenergic Receptor-Mediated Taurine Release from Astroglial Cells Are Independent of Manipulations of Intracellular Calcium
}

\author{
W. Shain, ${ }^{1}$ J. A. Connor, ${ }^{2}$ V. Madelian, ${ }^{1}$ and D. L. Martin' \\ 'Laboratory of Neurotoxicology and Nervous System Disorders, Wadsworth Center for Laboratories and Research, \\ Albany, New York 12201 and Department of Environmental Health and Toxicology, School of Public Health, State \\ University of New York, Albany, New York 12201, and ${ }^{2}$ AT\&T Bell Laboratories, Murray Hill, New Jersey 07974
}

\begin{abstract}
Stimulation of beta-adrenergic receptors on LRM55 astroglial cells results in CAMP-dependent release of taurine. We have previously demonstrated that extracellular $\mathrm{Ca}^{2+}$ is not required for either spontaneous or receptor-mediated taurine release (Martin et al., 1988b). In the present series of experiments we investigated the relationship between changes in intracellular free $\mathrm{Ca}^{2+}\left(\left[\mathrm{Ca}^{2+}\right]_{1}\right)$ and taurine release. $\left[\mathrm{Ca}^{2+}\right]_{i}$ was measured using the fluorescent probe fura-2 and was manipulated by changing the concentration of $\mathrm{Ca}^{2+}$ in the incubation medium and by using the $\mathrm{Ca}^{2+}$ ionophore ionomycin. $\left[\mathrm{Ca}^{2+}\right]$, was reduced from $150 \pm 95 \mathrm{nM}$ ( $n$ $=46$ ) in control medium (containing $1.1 \mathrm{mM} \mathrm{CaCl}_{2}$ ) to $46 \pm$ $10 \mathrm{nM}(n=43)$ in saline containing no $\mathrm{CaCl}_{2}$ and $10 \mu \mathrm{M}$ EGTA. $\left[\mathrm{Ca}^{2+}\right]_{1}$ was rapidly elevated to $\geq 1 \mu \mathrm{M}$ in medium containing $100 \mu \mathrm{M} \mathrm{CaCl}$ and $10 \mu \mathrm{M}$ ionomycin. Taurine release, either spontaneous or stimulated by isoproterenol, was not significantly affected by these manipulations of $\left[\mathrm{Ca}^{2+}\right]_{i}\left[\mathrm{Ca}^{2+}\right]_{i}$ did not change when cells were stimulated with $100 \mathrm{~nm}$ isoproterenol in either control saline containing $1.1 \mathrm{mM} \mathrm{CaCl}$ or in $\mathrm{CaCl}_{2}$-free saline containing $10 \mu \mathrm{M}$ EGTA. Other secretogogs (serotonin and ethanol) did not cause changes in $\left[\mathrm{Ca}^{2+}\right]_{i \text { - }}$ These data indicate that neither spontaneous or receptormediated taurine release from astroglial cells is $\mathrm{Ca}^{2+}$ dependent. However, when cells were preloaded with $\mathrm{Ca}^{2+}$, allowed to recover briefly, and then stimulated with isoproterenol, it was possible to demonstrate transient increases in $\mathrm{Ca}^{2+}$. Since these observations were made in $\mathrm{CaCl}_{2}$-free medium containing $10 \mu \mathrm{M}$ EGTA, the $\mathrm{Ca}^{2+}$ released was probably from internal stores. When taurine release was examined using these same conditions responses were similar to controls, indicating that $\mathrm{Ca}^{2+}$, released from intracellular stores, does not function to facilitate taurine release.
\end{abstract}

Receptor-mediated release of the neuroactive inhibitory amino acid taurine may be an important function of astrocytes (Martin et al., 1988). Direct evidence for this glial cell function has

\footnotetext{
Received June 17, 1988; revised Dec. 28, 1988; accepted Dec. 29, 1988.

The work leading to this communication was sponsored in part by grants NS21219 and AA07155 awarded to W.S., contract F49620 from AFOSR awarded to J.A.C. and contract N1487GO179 awarded to D.L.M. by the Naval Medical Research and Development Command. We also thank Ms. K. Marczak, A. Whirtley, and E. LaVigne for their contributions.

Correspondence should be addressed to W. Shain, Laboratory of Neurotoxicology and Nervous System Disorders, Wadsworth Center for Laboratories and Research, Empire State Plaza, Box 509, Albany, NY 12201-0509.

Copyright (C) 1989 Society for Neuroscience $0270-6474 / 89 / 072306-07 \$ 02.00 / 0$
}

been obtained using primary cell cultures and LRM55 astroglial cells (Shain and Martin, 1984; Perrone et al., 1986; Shain et al., 1986; Madelian and Shain, 1987; Shain et al., 1987b). Indirect evidence, consistent with this hypothesis, has been obtained by measuring taurine release from kainate-lesioned hippocampus (Butcher et al., 1987).

Receptor-mediated release of most hormones and neurotransmitters occurs by exocytosis. We have begun to characterize the mechanism of receptor-mediated taurine release from astroglial cells by determining if the process has properties similar to exocytotic release. One property of exocytotic release is that it is $\mathrm{Ca}^{2+}$ dependent. We have demonstrated that receptor-mediated taurine release from astroglia is not associated with a change in $\mathrm{Ca}^{2+}$ permeability through known types of $\mathrm{Ca}^{2+}$ channels since release occurs in the presence of the $\mathrm{Ca}^{2+}$ channel blockers diltiazam, nifedipine, and verapamil and when $\mathrm{Ca}^{2+}$ in the extracellular medium is replaced by $\mathrm{Mn}^{2+}, \mathrm{Cd}^{2+}$, or $\mathrm{Co}^{2+}$ (Martin et al., 1989). Furthermore, taurine release from astroglia may not be dependent on any increase in plasma-membrane $\mathrm{Ca}^{2+}$ permeability since neither spontaneous nor receptor-mediated release is affected by removing $\mathrm{Ca}^{2+}$ from the incubation medium (Martin et al., 1989).

While these data suggest that taurine release from astroglia is distinctly different from exocytotic synaptic release from neurons, they do not indicate whether taurine release from astroglial cells is $\mathrm{Ca}^{2+}$ independent or whether release is dependent on $\mathrm{Ca}^{2+}$ mobilized from intracellular stores. In order to investigate whether receptor-mediated taurine release depends on the concentration of free cytoplasmic $\mathrm{Ca}^{2+}\left(\left[\mathrm{Ca}^{2+}\right]_{\mathrm{i}}\right)$, we studied cytoplasmic $\mathrm{Ca}^{2+}$ levels in LMR55 astroglial cells using the florescent $\mathrm{Ca}^{2+}$ indicator fura-2 (Grynkiewicz et al., 1985). Our results indicated that (1) $\left[\mathrm{Ca}^{2+}\right]_{i}$ can be decreased by removing $\mathrm{Ca}^{2+}$ from the extracellular medium or greatly increased by exposing cells to media containing $\mathrm{Ca}^{2+}$ and the $\mathrm{Ca}^{2+}$-ionophore ionomycin (Liu and Hermann, 1978), (2) neither increasing nor decreasing $\left[\mathrm{Ca}^{2+}\right]_{i}$ affected the rates of spontaneous or receptormediated taurine release, (3) stimulation of beta-adrenergic receptors, which induces taurine release, does not result in an increase in $\left[\mathrm{Ca}^{2+}\right]_{i}$ under conventional incubation conditions. Thus, we conclude that receptor-mediated taurine release from astroglia occurs by a process distinct from exocytosis and transmitter release from neurons since it does not depend on changes in $\left[\mathrm{Ca}^{2+}\right]_{\mathrm{i}}$. Under specifically defined conditions, e.g., when cells are extensively preloaded with $\mathrm{Ca}^{2+}$, we found that beta-adrenergic stimulation can mediate an increase in $\left[\mathrm{Ca}^{2+}\right]_{\mathrm{i}}$ by releasing 
$\mathrm{Ca}^{2+}$ from intracellular stores. Similar treatment of cells did not result in changes of either spontaneous or receptor-mediated taurine release.

\section{Materials and Methods}

Materials. (-)-Isoproterenol was purchased from Sigma (St. Louis, MO). Ionomycin was purchased from Calbiochem (San Diego, CA). Fura-2 acetoxy-methyl ester (fura-2/AM) was purchased from Molecular Probes (Junction City, OR). ${ }^{3} \mathrm{H}$-taurine and scintillation counting solution (ACS) were purchased from Amersham (Chicago, IL). All other chemicals were purchased at the highest possible purity.

Cell cultures and media. LRM55 astroglial cells were used for all experiments. This continuous cell line exhibits a number of astrocytic phenotypes including $\mathrm{HCO}_{3} / \mathrm{Cl}^{-1}$ exchange (Wolpaw and Martin, 1984), glutamine synthesis activity (Waniewski and Martin, 1984), glial fibrillary acidic protein (W. Shain, unpublished observations) receptormediated shape-change (Shain et al., 1987a), and receptor-mediated taurine release (Shain and Martin, 1984). Cells were maintained as mass cultures in $100 \mathrm{~mm}$ dishes with modified F12 medium (Vogel et al., 1972 ) supplemented with $5 \%$ fetal bovine serum. For release experiments, cells were transferred to pieces of cell support film (Bellco, Vineland, NJ) and grown to confluency. For intracellular $\mathrm{Ca}^{2+}$ measurements, cells were transferred to glass cover slips (\#1, $18 \mathrm{~mm}$ diameter) and allowed to grow until approximately $50 \%$ confluent.

Three different saline solutions were used to maipulate $\left[\mathrm{Ca}^{2+}\right]_{\mathrm{i}}$. All 3 were buffered with HEPES adjusted to $\mathrm{pH} 7.3$ with $\mathrm{NaOH}$ and supplemented with $0.1 \mathrm{gm} /$ liter sodium ascorbate. Control saline was HEPESbuffered Hanks saline (HHA; Martin and Shain, 1979) and contained $1.1 \mathrm{mM} \mathrm{CaCl}_{2}$ as the only added calcium salt. The saline used to lower $\left[\mathrm{Ca}^{2+}\right]_{\mathrm{i}}$ was made by omitting all of the $\mathrm{CaCl}_{2}$ from $\mathrm{HHA}$, adding 3.3 mM sucrose to maintain osmolarity, and adding $10 \mu \mathrm{M}$ EGTA to buffer any contaminating $\mathrm{Ca}^{2+}$ from other constituents. This medium was designated low- $\mathrm{Ca}^{2+} \mathrm{HHA}$ (LCHHA). $\left[\mathrm{Ca}^{2+}\right]_{\mathrm{i}}$ was increased by using the $\mathrm{Ca}^{2+}$ ionophore ionomycin (Calbiochem) in a reduced-Ca ${ }^{2+} \mathrm{HHA}$ (RCHHA). This medium was prepared by reducing the concentration $\mathrm{CaCl}_{2}$ to $100 \mu \mathrm{M}$ and adding $3.2 \mathrm{~mm}$ sucrose. Ionomycin was added at $1-100 \mu \mathrm{M}$.

Taurine release. Taurine release was measured by using a perfusion method that we have described previously (Shain and Martin, 1984). Briefly, cells were loaded with tracer quantities of ${ }^{3} \mathrm{H}$-taurine $(10 \mu \mathrm{Ci} /$ $\mathrm{ml} ; 300 \mathrm{nM}$ ), washed free of radiolabeled substrate, loaded into a glass perfusion column (final volume, 250 or $500 \mu \mathrm{l}$ ), and continuously perfused with $\mathrm{HHA}$ at $0.5 \mathrm{ml} / \mathrm{min}$. The eluent was collected as 1 min fractions. Changes in perfusion salines or drug applications were made by means of a series of in-line valves. Taurine release was monitored as ${ }^{3} \mathrm{H}$-taurine by scintillation counting. The data were analyzed by calculating the fractional rate of release for each $1 \mathrm{~min}$ sample during the entire course of the experiment.

Measurement of intracellular $\mathrm{Ca}^{2+}$. Intracellular $\mathrm{Ca}^{2+}$ concentrations $\left(\left[\mathrm{Ca}^{2+}\right]_{i}\right)$ were measured by determining the ratio of the fluorescence of fura-2 using excitation at 340 and $380 \mathrm{~nm}$ as described previously (Connor et al., 1987a, b, 1988). Cells were loaded with the fluorescence indicator by incubation with fura-2/AM (final concentration, $5 \mu \mathrm{M}$ ) in growth medium for $30 \mathrm{~min}$ at $37^{\circ} \mathrm{C}$. Intracellular fura- 2 concentrations were estimated to be in the range of $100-300 \mu \mathrm{M}$ by methods described elsewhere (Tsien et al., 1985; Connor et al., 1987a, b). Two coverslips were incubated at one time. One of these was washed with HHA and directly mounted into the recording chamber. The second was rinsed 3 times with HHA and incubated at room temperature until used (1.5-2 $\mathrm{hr}$ ). These incubation times and the maintenance of the cells at room temperature after loading with fura-2/AM were used to reduce compartmentalization and extrusion of the indicator. Excitation light was passcd through narrow-band interference filters centered at 340 and 380 $\mathrm{nm}$ to a UV-F $4 \mathrm{O} \times$ objective (Nikon) in an epiillumination configuration. The emission signal was filtered with a $480 \mathrm{~nm}$ long-pass filter. Exposure time for individual frames was $0.5 \mathrm{sec}$ with a frame pair (340, $380 \mathrm{~nm}$ ), separated by approximately $1 \mathrm{sec}$. A cooled, charge-coupleddevice camera (Photometrics Ltd., Tucson, AZ, model 81-A) was used as the photodetector. The $140 \times 240$ pixel images were stored and analyzed by using a DEC LSI 11-73-based computer and photographed from a video monitor. Intracellular $\mathrm{Ca}^{2+}$ concentrations were calculated from the fluorescence ratios (340/380) using the following equation:

$$
\left[\mathrm{Ca}^{2+}\right]_{\mathrm{i}}=K_{D}\left[\left(R-R_{\min }\right) /\left(R_{\max }-R\right)\right]\left(F_{\mathrm{o}} / F_{s}\right),
$$

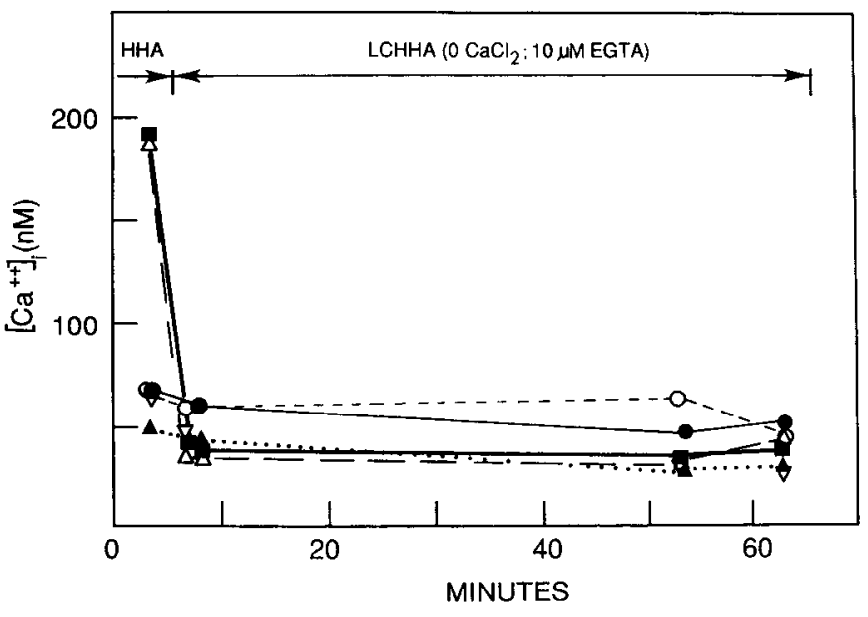

Figure 1. Changes in $\left[\mathrm{Ca}^{2+}\right]_{\mathrm{i}}$ observed when cells were exposed to $\mathrm{Ca}^{2+}$ frec media. At the time indicated the medium in the recording chamber was changed by removing HHA, washing 3 times with LCHHA, and then continuing incubation in LCHAA. Each symbol represents the data from an individual cell. In other experiments, measurements were made at intermediate times, resulting in values similar to those indicated by the extrapolated lines.

where $R_{\min }=0.45, R_{\max }=11.7, F_{0} / F_{\mathrm{s}}=7.5$, and $K_{D}=225 . R$ is the observed ratio of the fluorescence intensity excited by 340 and $380 \mathrm{~nm}$ illumination, respectively.

\section{Results}

The experiments reported here were designed to investigate the relationship between taurine release and intracellular $\mathrm{Ca}^{2+}$ levels and to test the possibility that release is facilitated by $\mathrm{Ca}^{2+}$ released from intracellular stores.

The first series of experiments was designed to determine if the $\left[\mathrm{Ca}^{2+}\right]_{i}$ of LRM55 astroglial cells could be manipulated by either changing the extracellular $\mathrm{Ca}^{2+}$ concentration or increasing membrane permeability to $\mathrm{Ca}^{2+}$ by using the selective ionophore ionomycin (Kauffman et al., 1980). $\left[\mathrm{Ca}^{2+}\right]_{i}$ levels were quite variable in cells bathed in control saline (HHA); the mean $\left[\mathrm{CA}^{2+}\right]_{\mathrm{i}}$ was $150 \pm 95 \mathrm{~nm}(n=46)$. When the saline was changed from HHA to LCHHA (see Materials and Methods), $\left[\mathrm{Ca}^{2+}\right]_{\text {i }}$ decreased to approximately $50 \mathrm{~nm}$ and was maintained at that level for as long as cells were observed (60 min; Fig. 1). The mean $\left[\mathrm{Ca}^{2+}\right]_{\mathrm{i}}$ for cells incubated in LCHHA for $>3 \mathrm{~min}$ was $47.0 \pm 10.1(n=43)$. When the saline was changed from HHA to RCHHA (see Materials and Methods) with ionomycin, $\left[\mathrm{Ca}^{2+}\right]_{\mathrm{i}}$ increased rapidly and dramatically to concentrations $>1 \mu \mathrm{M}$ (Fig. 2). At these high $\left[\mathrm{Ca}^{2+}\right]_{\mathrm{i}}$ values it became difficult to calculate $\left[\mathrm{Ca}^{2+}\right]_{\mathrm{i}}$ because the fluorescence at $380 \mathrm{~nm}$ excitation became extremely weak.

Release experiments were designed to parallel those used to measure $\left[\mathrm{Ca}^{2+}\right]_{i}$. In a typical experiment, cells were first perfused with HHA for $30 \mathrm{~min}$ (Fig. 3). During this time there was an initial washout of ${ }^{3} \mathrm{H}$-taurine followed by a relatively constant baseline rate of release. All measurements of taurine release were made after the spontaneous release rate had reached the constant baseline rate. A control response to $100 \mathrm{nM}$ IPR was elicited before the perfusion medium was changed to manipulate intracellular $\mathrm{Ca}^{2+}$.

The effect of increasing $\left[\mathrm{Ca}^{2+}\right]_{\mathrm{i}}$ on taurine release was determined by incubating cells with ionomycin $(10 \mu \mathrm{M})$. In these experiments, cells were exposed to RCHHA for $30 \mathrm{~min}$, after which a control response to IPR was obtained (Fig. 3). Cells 


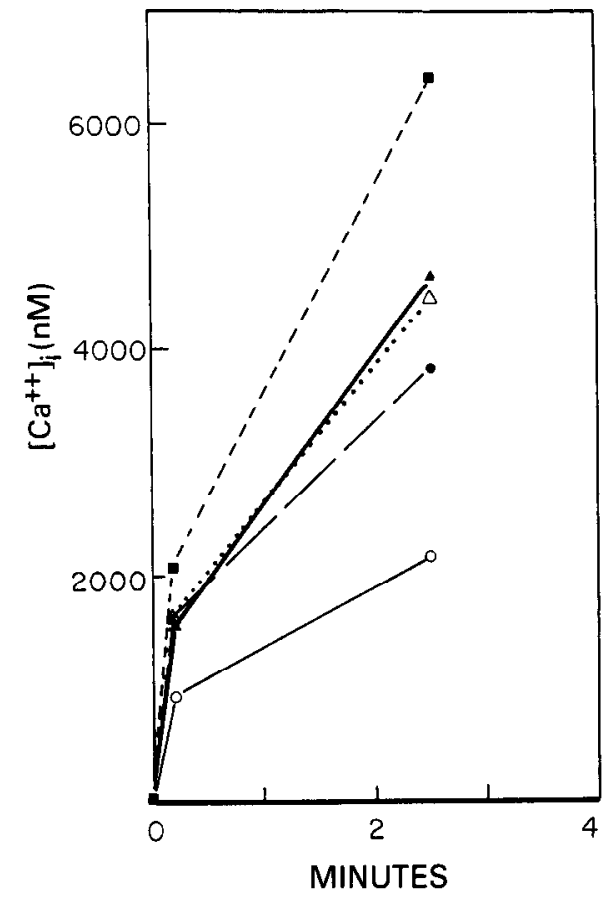

Figure 2. Changes in $\left[\mathrm{Ca}^{2+}\right]_{\mathrm{i}}$ observed when cells were exposed to RCHHA containing $10 \mu \mathrm{M}$ ionomycin. The change in medium was made as described for Figure 1. Each symbol represents the data from an individual cell.

were then exposed to ionomycin alone or to ionomycin and IPR. Ionomycin did not stimulate release when applied alone, nor did it potentiate IPR-stimulated release. These data indicate that directly increasing $\left[\mathrm{Ca}^{2+}\right]_{i}$ does not stimulate taurine release. We have also demonstrated that both spontaneous and receptormediated taurine release were not affected by removing extracellular $\mathrm{Ca}^{2+}$ (Martin et al., 1988b).

In a third series of experiments, $\left[\mathrm{Ca}^{2+}\right]_{\mathrm{i}}$ was measured while the cells were stimulated with $100 \mathrm{nM}$ IPR. Cells were exposed to IPR in medium containing $1.1 \mathrm{mM} \mathrm{CaCl}_{2}$ (HHA; Fig. $4 . A$ ) or in LCHHA after $\left[\mathrm{Ca}^{2+}\right]_{i}$ had dropped to lower concentrations (Fig. $4 B$ ). No changes in $\left[\mathrm{Ca}^{2+}\right]_{i}$ were observed. Several other taurine secretogogs were tested for their abilities to affect $\left[\mathrm{Ca}^{2+}\right]_{i}$. Stimulation with serotonin $(10 \mu \mathrm{M})$ or ethanol $(100 \mathrm{~mm})$ did not cause observable changes in $\left[\mathrm{Ca}^{2+}\right]_{\text {i. }}$.

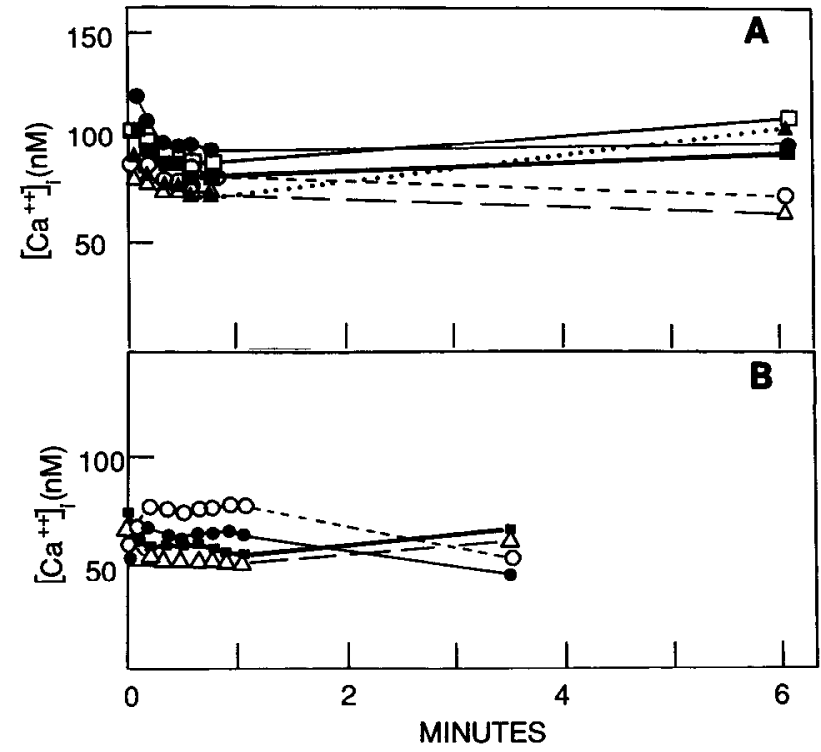

Figure 4. Effect of $100 \mathrm{nM}$ isoproterenol on $\left[\mathrm{Ca}^{2+}\right]_{\mathrm{i}}$ when cells were incubated in HHA $(A)$ or LCHHA $(B)$. Each symbol represents an individual cell.

From the preceding experiments we conclude that neither spontaneous nor receptor-mediated taurine release is affected by changing $\left[\mathrm{Ca}^{2+}\right]_{\mathrm{i}}$ and that stimulation of beta-adrenergic receptors under normal conditions does not result in changes in $\left[\mathrm{Ca}^{2+}\right]_{\text {i }}$.

Under specialized conditions, however, we did observe betaadrenergic receptor-mediated release of $\mathrm{Ca}^{2+}$ from what must be intracellular stores. If cells were first exposed to LCHHA for a prolonged period (15-60 min), returned to normal saline, and then returned to LCHHA before drug application, an increase in $\left[\mathrm{Ca}^{2+}\right]_{i}$ was observed. A representative experiment is illustrated in Figure 5. When cells were changed from HHA to LCHHA, a reduction in $\left[\mathrm{Ca}^{2+}\right]_{i}$ was observed. Panels are designated by the total time in minutes that the cells had been mounted on the microscope. Cells were changed from (6.30min panel) HHA to LCHHA at $9 \mathrm{~min}$. The 39.53-min panel shows $\left[\mathrm{Ca}^{2+}\right]_{\mathrm{i}}$ approximately $30 \mathrm{~min}$ after the exchange for LCHHA at $9 \mathrm{~min}$. The shape and relative position of the 8 cells
Figure 3. Effects of increasing $\left[\mathrm{Ca}^{2+}\right]_{\mathrm{i}}$ on spontaneous and receptor-mediated release. Isoproterenol, $100 \mathrm{nM}$, and ionomycin, $10 \mu \mathrm{M}$, were added during the times indicated by the bars. The medium was changed from HHA to $\mathrm{RCHHA}$ as indicated.

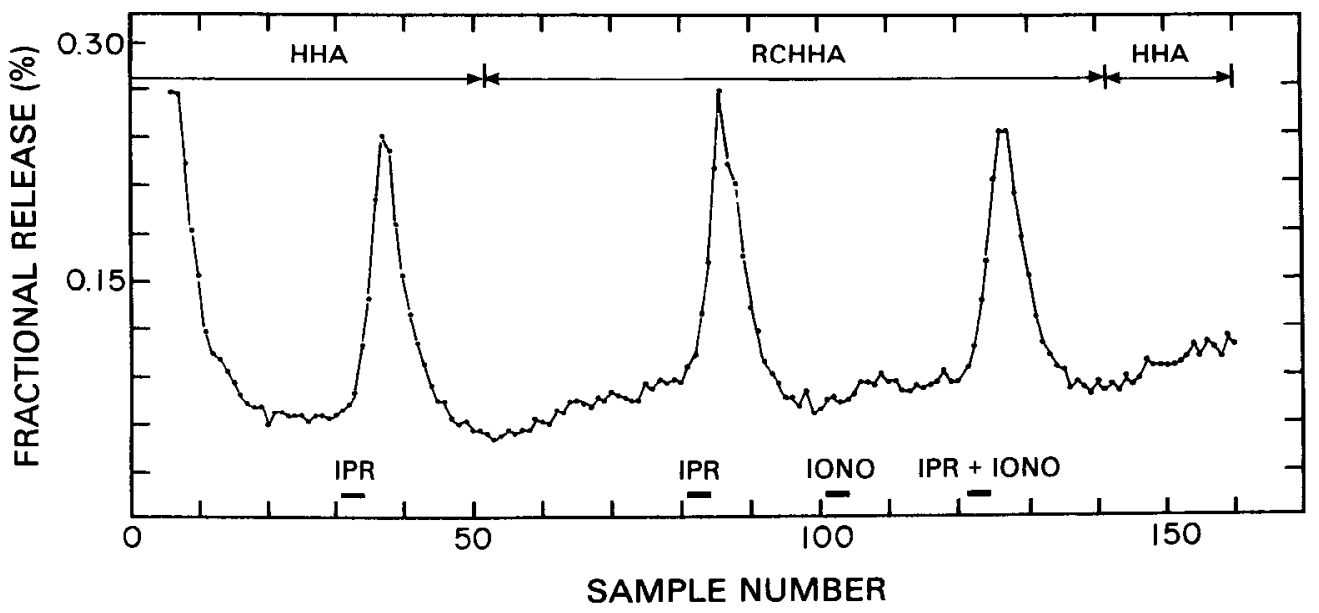


in the field are shown in the simple fluorescence picture at the bottom right of the series.

The cells were returned to normal saline at $\mathbf{4 2 . 5} \mathrm{min}$, and the next 5 ratio measurements were taken in rapid succession (42.68$43.25 \mathrm{~min})$. These panels show that $\left[\mathrm{Ca}^{2+}\right]_{i}$ increases dramatically, but with different time courses in all the cells. Over the

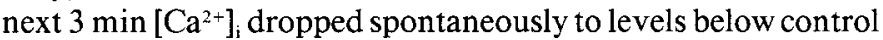
$(46.10 \mathrm{~min})$. These data have been quantified and presented in Figure $6 \mathrm{~A}$. When the HHA was again exchanged for LCHHA the levels dropped further and remained low (53.67 and 55.87 $\mathrm{min}$ ). In these 2 panels, there are quite noticeable areas of higher $\left[\mathrm{Ca}^{2+}\right]_{i}$ around the nucleus that are especially evident in the lower left-hand cell. This type of pattern is a common observation in astroglial cells, as well as in other types of cells (Benjamin et al., 1988). Isoproterenol $(100 \mu \mathrm{M})$ was added to the LCHHA during the interval between 55.87 and $56.01 \mathrm{~min}$ and the time course of $\left[\mathrm{Ca}^{2+}\right]_{i}$ changes followed at $15 \mathrm{sec}$ intervals over the next $2 \mathrm{~min}(56.01-58.5 \mathrm{~min})$. There was a transient, nonsynchronized rise in $\left[\mathrm{Ca}^{2+}\right]_{\mathrm{i}}$ in 6 of the 8 cells. These data were quantified and are presented in Figure $6 B$. The apparent peak of the responses varied greatly from cell to cell, but this may be because we missed the maxima of these relatively short, transient changes. $\left[\mathrm{Ca}^{2+}\right]_{\mathrm{i}}$ distribution during the peak response of the large flat cell in the lower left of panel for $56.29 \mathrm{~min}$ is interesting because many of the regions of highest $\left[\mathrm{Ca}^{2+}\right]_{i}$ before stimulation $(55.87 \mathrm{~min})$ are among the lowest during the response. Since these cells were in LCHHA at the time of the response and had been in this saline for the previous $3 \mathrm{~min}$, the $\mathrm{Ca}^{2+}$ responsible for the indicator signal, in all probability, came from intracellular stores that were loaded as a result of the cycle through normal (HHA) and $\mathrm{Ca}^{2+}$-free saline (LCHHA). Since these were the only conditions under which we observed clear increases in $\left[\mathrm{Ca}^{2+}\right]_{i}$ from intracellular stores, we examined taurine release under similar conditions (Fig. 7). No demonstrable effect on taurine release was observed. When $\mathrm{Ca}^{2+}$ is released from intracellular stores, taurine release is not affected.

\section{Discussion}

The data presented in this report indicate that receptor-mediated release of taurine from astroglia is not dependent on $\mathrm{Ca}^{2+}$. This conclusion is bascd on 4 lines of cvidence. First, receptormediated taurine release is unaffected when $\mathrm{Ca}^{2+}$ is eliminated from the perfusion medium, is not blocked by substituting $\mathrm{Cd}^{2+}$, $\mathrm{Co}^{2+}$, and $\mathrm{Mn}^{2+}$ for extracellular $\mathrm{Ca}^{2+}$, and is not inhibited by the organic $\mathrm{Ca}^{2+}$ channel blockers nifedipine, diltiazem, and veratradine (Martin et al., 1989). Thus, extracellular $\mathrm{Ca}^{2+}$ is not involved. Second, stimulation of beta-adrenergic receptors by protocols that cause the release of taurine from astrocytes does not in ordinary circumstances result in changes of $\left[\mathrm{Ca}^{2+}\right]_{i}$. Third, conditions that decrease or increase $\left[\mathrm{Ca}^{2+}\right]_{\mathrm{i}}$ over a range from $<50 \mathrm{nM}$ to $>1 \mu \mathrm{M}$ have no effect on receptor-mediated taurine release. And finally, taurine release is not stimulated by procedures that increase $\left[\mathrm{Ca}^{2+}\right]_{i}$ to $>1 \mu \mathrm{M}$. Therefore, receptormediated taurine release from astroglia is distinctly different from the $\mathrm{Ca}^{2+}$-dependent exocytotic release of neurotransmitters from neurons. This conclusion is, perhaps, not surprising, as astrocytes are not known to have specialized ccll-cell contacts, i.e., concentrations of exocytotic vesicles and presynaptic specializations.

$\mathrm{Ca}^{2+}$ dependency of taurine release has been studied in several in vitro preparations, including primary cultures of astrocytes and retina. Philibert et al. (1988) studied the $\mathrm{Ca}^{2+}$ dependency of $\mathrm{K}^{+}$-stimulated taurine release from primary cultures of astrocytes. They observed that $\mathrm{K}^{+}$-stimulated taurine rclcasc was inhibited by $10 \mathrm{mM} \mathrm{Mg}^{2+}$ and that no additional $\mathrm{K}^{+}$-stimulated release was observed after treating cells with 1 mM EGTA. Treatment with $1 \mathrm{~mm}$ EGTA resulted in a large increase in spontaneous activity. They concluded that $\mathrm{K}^{+}$-stimulated taurine release was $\mathrm{Ca}^{2+}$-independent. We found that IPR-stimulated taurine release was similarly inhibited by $10 \mathrm{mM} \mathrm{Mg}^{2+}$ but concluded that this effect was due to the elevated osmotic pressure of the medium since these effects could be mimicked by equiosmolar changes using sucrose or $\mathrm{NaCl}$ (Martin et al., 1989). We also found that perfusion with medium containing I mM EGTA caused a large increase in spontaneous taurine release, resulting in a lack of response to IPR (Martin et al., 1989). Our observations are, therefore, very similar to those of Philibert et al. (1988). However, the results presented here and from other experiments, including those with $\mathrm{Ca}^{2+}$ channel blockers (Martin et al., 1989), have led us to a different conclusion-taurinc release from astroglial cells is $\mathrm{Ca}^{2+}$ independent. Taurine efflux from a neuroblastoma $\times$ glioma hybrid was $\mathrm{Ca}^{2+}$ independent but also could not be stimulated by high external $\mathrm{K}^{+}$(Kruzinger and Hamprecht, 1981). Lombardini (1988) reported that taurine release from retinal homogenates is $\mathrm{Ca}^{2+}$ independent and is stimulated by high $\mathrm{K}^{+}$but not depolarizing agents, and he concluded that this release occurs from glial components.

Taurine release has been observed with neural tissues in vitro (Bernardi et al., 1984; Lehmann et al., 1985; Tossman et al., 1985; Girault et al., 1986) and in vivo by using indwelling perfusion techniques (Collins and Topiwala, 1974; Korpi and Oja, 1983; Kontro and Oja, 1987). The cellular origin of this release was left unclear by these studies; however, Butcher et al. (1987), who used kainate to lesion neurons selectively, still demonstrated taurine release. The $\mathrm{Ca}^{2+}$ independency of astrocytic taurine release provides a tool that may help to distinguish astrocytic release from exocytotic neuronal release in studies with more intact tissue preparations. However, recent reports indicate that $\mathrm{Ca}^{2+}$ dependency, by itself, will not be sufficient to distinguish astrocytic and neuronal release, as $\mathrm{Ca}^{2+}$-independent release has been observed in platelets (Rink et al., 1982) and neurons (Schwartz, 1987). The mechanism of this release has not been described.

There have been relatively few studies of $\mathrm{Ca}^{2+}$ entry or cytoplasmic free $\mathrm{Ca}^{2+}$ in astrocytes. $\mathrm{Ca}^{2+}$ can enter cells through $\mathrm{Ca}^{2+}$-selective ion channels that may be voltage dependent or receptor activated (Miller, 1987). Voltage-dependent $\mathrm{Ca}^{2+}$ channels have been observed in astroglial cells, and ion influx is particularly prominent when $\mathrm{Ba}^{2+}$ is substituted for $\mathrm{Ca}^{2+}$ (MacVicar, 1984). Under other conditions, e.g., normal $\mathrm{Ca}^{2+}$ concentrations, different authors using different preparations have reported that $\mathrm{Ca}^{2+}$ fluxes are (Lazarewicz et al., 1977; Newman, 1985) or are not (Barnes and Mandel, 1981; Walz and Wilson, 1986) voltage dependent. LRM55 astroglial cells appear not to have voltage-sensitive $\mathrm{Ca}^{2+}$ channels since depolarization of cells in HHA containing $1.1 \mathrm{mM} \mathrm{CaCl}_{2}$ and $50 \mathrm{~mm} \mathrm{KCl}$ does not cause changes in cytoplasmic free $\mathrm{Ca}^{2+}(W$. Shain and J. A. Connor, unpublished observations).

Rcceptor-mediatcd changes in $\left[\mathrm{Ca}^{2+}\right]_{1}$ have been reported in C6 glioma cells after stimulation with serotonin (Sugino et al., 1984). However, serotonin did not cause increases in $\mathrm{Ca}^{2+}$ in LRM55 astroglial cells, nor have we observed changes in cytoplasmic free $\mathrm{Ca}^{2+}$ following stimulation by isoproterenol, the kappa-opiate U-50,488, or ethanol when cells were continuously 

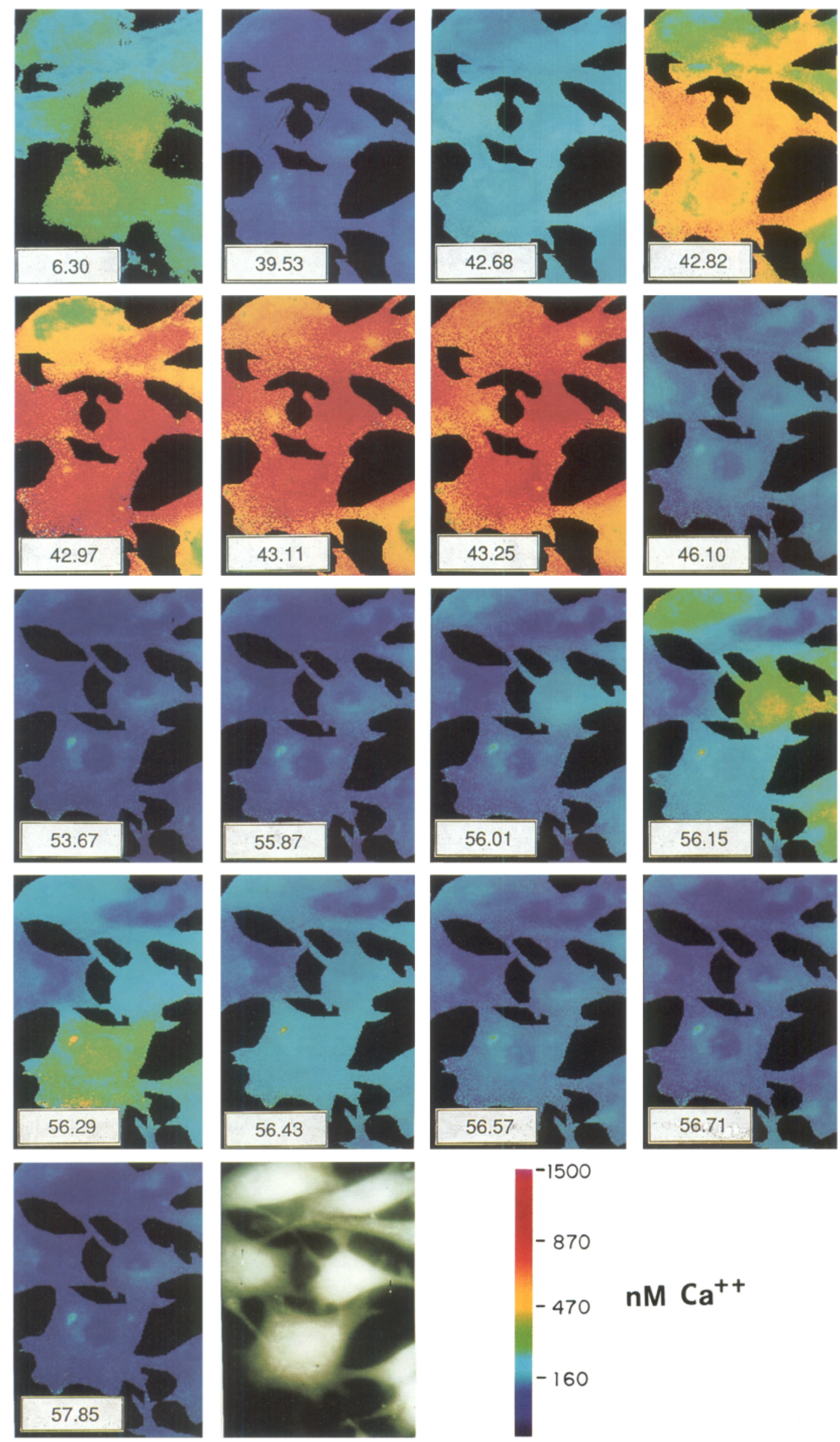

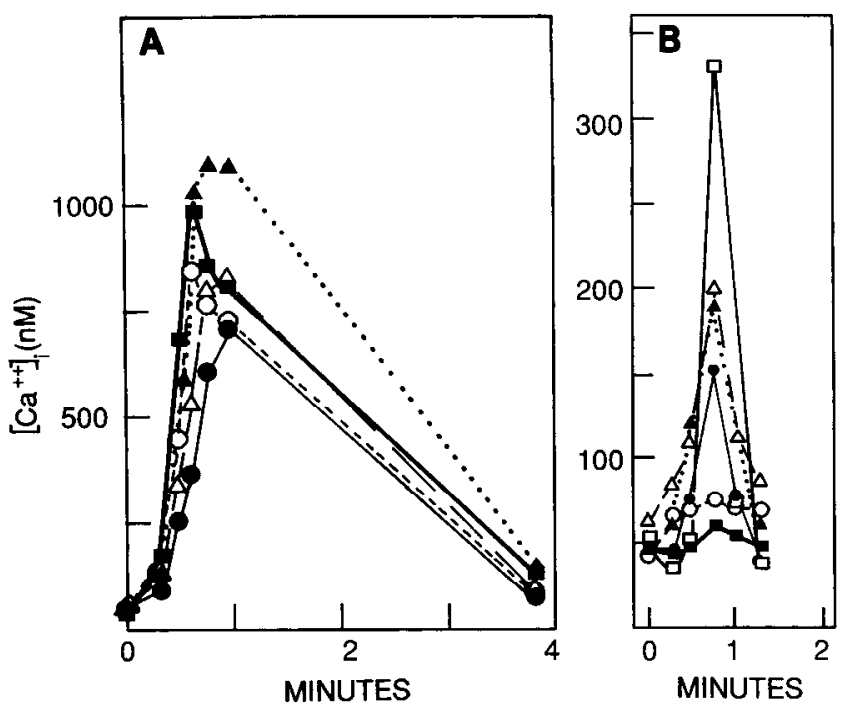

Figure 6. Quantification of changes in $\left[\mathrm{Ca}^{2+}\right]_{\mathrm{i}}$ following changes from LCHHA to HHA beginning at $42.68 \mathrm{~min}(A)$ and after isoproterenol stimulation upon return to LCHHA beginning at $55.87 \mathrm{~min}(B)$. The data are presented for individual cells.

incubated in HHA. However, we did find that intracellular $\mathrm{Ca}^{2+}$ increased upon stimulation with IPR if the cells were preloaded with $\mathrm{Ca}^{2+}$. This increase in $\left[\mathrm{Ca}^{2+}\right]_{\mathrm{i}}$ appears to be due to release from intracellular stores and not to $\mathrm{Ca}^{2+}$ from the extracellular medium since the responsc was obscrved in medium devoid of extracellular $\mathrm{Ca}^{2+}$ (LCHHA). Because no response was observed in normal HHA or LCHHA if the cells were not preloaded, intracellular storage sites may usually be depleted. It is possible that the differences between the results with C6 and LRM55 cells may be related to differences in the experimental handling of the cells or to differences in basal $\mathrm{Ca}^{2+}$ storage between the cell lines.

Finally, the observation of regional differences in $\mathrm{Ca}^{2+}$ levels within cells as shown in Figure 5 is common when cells have been loaded by using the /AM form of fura-2 (Williams et al., 1985; Benjamin et al., 1988; Connor and Tseng, 1988). Such differences are not seen where the ionic form of the indicator has been injected into either Purkinje neurons or fibroblasts (Connor and Tseng, 1988; C. W. Benjamin, J. A. Connor, and R. R. Gorman, unpublished observations). In these studies the injected indicator demonstrates uniform $\mathrm{Ca}^{2+}$ levels, even in fibroblasts where the fura-2/AM-loaded indicator demonstrates distributions almost identical to those shown here in astrocytes. By comparing data from injected and fura-2/AM-loaded fibroblasts, it appears that the signal measured in the portion of the cell occupied by the nucleus most accurately reflects cytoplasmic $\mathrm{Ca}^{2+}$ levels, while areas surrounding the nucleus, where the indicator often demonstrates significantly higher levels, are heavi-

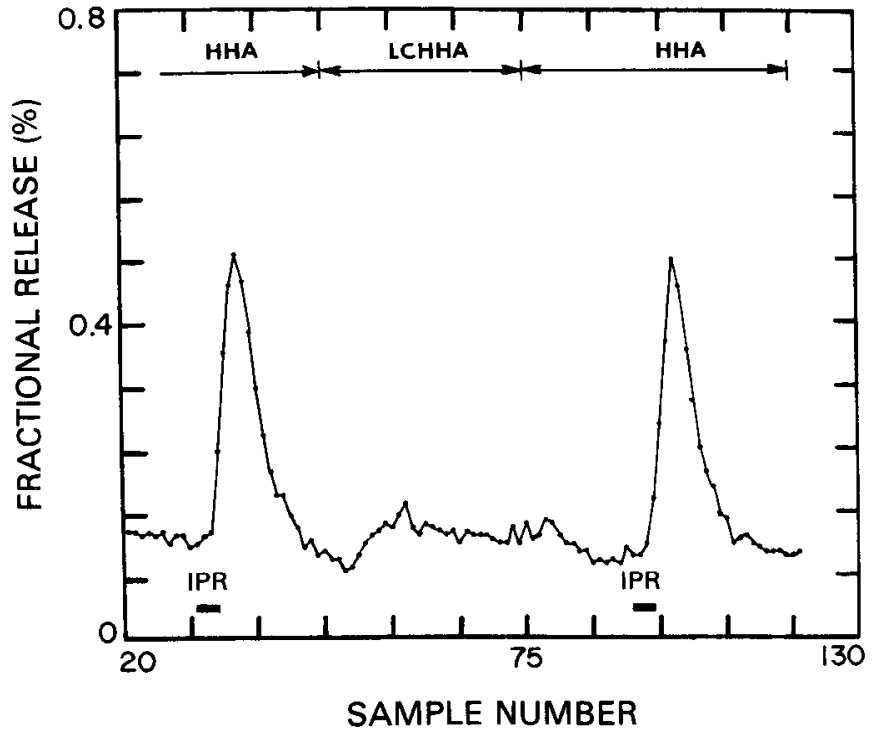

Figure 7. Effects of stimulating $\mathrm{Ca}^{2+}$ from intracellular stores on taurine release. Conditions were similar to those used to measure $\left[\mathrm{Ca}^{2+}\right]_{i}$ in Figure 5. $\Lambda$ control response to $100 \mathrm{~nm}$ isoproterenol was obtained in HHA. The medium was changed to LCHHA for $30 \mathrm{~min}$ with no observed decrease in taurine release. The medium was then changed back to HHA, again with no change in taurine release. This treatment produced a transient increase in $\left[\mathrm{Ca}^{2+}\right]_{\mathrm{i}}$ (see Figs. 5, 6A). Finally, cells were stimulated with $100 \mathrm{~nm}$ isoproterenol. Under these conditions this should produce a transient increase in $\left.\mathrm{C}^{2+}\right]_{\mathrm{i}}$ (see Higs. 5, 6B). The response to isoproterenol at this time was similar to that observed under control conditions.

ly influenced by the contents of intracellular stores (see middle records, Fig. 5). These areas correspond to the general location of the endoplasmic reticulum in astroglial cells (Shain et al., 1987a). We do not see any need to argue that the nucleus itself partitions $\mathrm{Ca}^{2+}$ differentially from the cytoplasm, as has been argued previously (Williams et al., 1985).

This mixing of signals, which at first glance might appear to be a disadvantage, is actually a benefit, as long as one does not attach too much importance to the absolute levels of $\mathrm{Ca}^{2+}$ reported, because the data give a simultaneous look at both cytoplasmic and compartmentalized $\mathrm{Ca}^{2+}$ levels. Our measurements clearly show that under standard conditions IPR does not change $\mathrm{Ca}^{2+}$ levels in any compartment accessible to fura2/AM during taurine release.

\section{References}

Barnes, E. M., and P. Mandel (1981) Calcium transport by primary cultured neuronal and glial cells from chick embryo brain. J. Neurochem. 36: 82-85.

Benjamin, C. W., J. A. Connor, W. G. Tarpley, and R. R. Gorman (1988) NIH-3T3 cells expressing the EJ-ras gene product exhibit reduced platelet derived growth factor-mediated $\mathrm{Ca}^{2+}$ mobilization Proc. Natl. Acad. Sci. USA 85: 4345-4349.

Figure 5. Stimulation of $\mathrm{Ca}^{2+}$ from intracellular stores. In order to observe release of $\mathrm{Ca}^{2+}$ from intracellular stores, the following protocol was followed. (Each panel is designated by the time in minutes after the fura- 2 measurements were initiated.) Cells in HHA (6.30 min) were washed with LCHHA and incubated for approximately $30 \mathrm{~min}(39.53 \mathrm{~min})$ to deplete intracellular $\mathrm{Ca}^{2+}$. The medium was changed back to $\mathrm{HHA}$ at 42.48 min and a transient increase in $\left[\mathrm{Ca}^{2+}\right]_{\mathrm{i}}$ was observed $(42.68-46.10 \mathrm{~min})$. HHA was replaced with LCHHA and cells incubated for approximately $7.5 \mathrm{~min}(53.67 \mathrm{~min})$. At $55.67 \mathrm{~min}$, isoproterenol was added to the incubation medium (final concentration, $100 \mathrm{nM}$ ). A transient increase in [Ca $\left.{ }^{2+}\right]$ was observed in all cells $(55.87-57.85 \mathrm{~min})$. The final micrograph illustrates the fluorescence image (excitation wave length $=380 \mathrm{~nm}$ ) of cells at the end of the experiment. The values of $\left[\mathrm{Ca}^{2+}\right]_{i}$ for the false colors are indicated by the bar. 
Bernardi, N., J. A. Assumpacao, C. G. Dacke, and N. Davidson (1984) Release of labelled taurine from the rat dorsal medulla and cerebellum in vivo. Pfluegers Arch. 401: 193-197.

Butcher, S. P., J. W. Lazarewicz, and A. Hamberger (1987) In vivo microdialysis studies on the effects of decortication and excitotoxic lesions in kainic acid-induced calcium fluxes, and endogenous amino acid release in the rat striatum. J. Neurochem. 49: 1355-1360.

Collins, G. C. S., and S. H. Topiwala (1974) The release of [14C]taurine from slices of rat cerebral cortex and spinal cord evoked by electrical stimulation and high potassium ion concentrations. $\mathrm{Br}$. J. Pharmacol. 50: 451 P-452P.

Connor, J. A., and H.-Y. Tseng (1988) Measurement of intracellular $\mathrm{Ca}^{2+}$ in cerebellar purkinje neurons in culture: Resting distribution and response to glutamate. Brain Res. Bull. 21:353-361.

Connor, J. A., M. C. Cornwall, and G. H. Williams (1987a) Spatially resolved cytosolic calcium response to angiotensin II and potassium in rat glomerulosa cells measured by digital imaging techniques. $J$. Biol. Chem. 262: 2919-2927.

Connor, J. A., H.-Y. Tseng, and P. E. Hockberger (1987b) Depolarization- and transmitter-induced changes in intracellular $\mathrm{Ca}^{2+}$ of rat cerebellar granule cells in explant cultures. J. Neurosci. 7: 1384-1400.

Connor, J. A., W. J. Wadman, P. E. Hockberger, and R. K. S. Wong (1988) Sustained dendritic gradients of $\mathrm{Ca}^{2+}$ induced by excitatory amino acids in CA1 hippocampal neurons. Science 240: 649-651.

Girault, J. A., L. Barbeito, U. Spampinato, H. Gozlan, J. Glowinski, and M.-J. Besson (1986) In vivo release of endogenous amino acids from the rat striatum: Further evidence for a role of glutamate and aspartate in corticostriatal neurotransmission. J. Neurochem. 47:98106.

Grynkiewicz, G., M. Poenie, and R. Y. Tsien (1985) A new generation of $\mathrm{Ca}^{++}$indicators with greatly improved fluorescence properties. $\mathrm{J}$. Biol. Chem. 260: 3440-3450.

Kauffman, R. F., R. W. Taylor, and D. R. Pfeiffer (1980) Cation transport and specificity of ionomycin. J. Biol. Chem. 255: 27352739.

Kontro, P., and S. S. Oja (1987) Taurine and GABA release from mouse cerebral cortex slices: Potassium stimulation releases more taurine than GABA from developing brain. Dev. Brain Res. 37: $277-$ 291.

Korpi, E. R., and S. S. Oja (1983) Characteristics of taurine release from cerebral cortex slices induced by sodium-deficient media. Brain Res. 289: 197-204.

Kurzinger, K., and B. Hamprecht (1981) $\mathrm{Na}^{+}$-dependent uptake and release of taurine by neuroblastoma $\times$ glioma hybrid cells. J. Neurochem. 37: 956-967.

Lazarewicz. J. W., M. Kanje, A. Sellstrom, and A. Hamburger (1977) Calcium fluxes in cultured and bulk isolated neuronal and glial cells. J. Neurochem. 29: 495-502.

Lehmann, A., J. W. Lazarewicz, and M. Zeise (1985) N-methylaspartate-evoked liberation of taurine and phosphoethanolamine in vivo: Site of release. J. Neurochem. 45: 1172-1177.

Liu, C.-M., and T. E. Hermann (1978) Characterization of ionomycin as a calcium ionophore. J. Biol. Chem. 253: 5892-5894.

Lombardini, J. B. (1988) Calcium-independent, potassium-stimulated release of taurine in retinal preparations obtained from the rat. J. Cell Biol. 107:508A

MacVicar, B. A. (1984) Voltage-dependent calcium channels in glial cells. Science 226: 1345-1347.

Madelian, V., and W. Shain (1987) Regulation of isoproterenol-induced cyclic AMP accumulation in LRM55 glial cells by phosphodiesterase. J. Pharmacol. Exp. Ther. 243: 618-623.

Martin, D. L., and W. Shain (1979) High affinity transport of taurine and $\beta$-alanine and low affinity transport of $\gamma$-aminobutyric acid by a single transport system in cultured glioma cells. J. Biol. Chem. 254: $7076-7084$

Martin, D. L., W. Shain, and V. Madelian (1988) Receptor-mediated release of taurine from glial cells and signaling between neurons and glia. In Glial Cell Receptors, H. K. Kimelberg, ed., pp. 183-195, Raven, New York.

Martin, D. L., V. Madelian, and W. Shain (1989) Spontaneous and beta-adrenergic receptor-stimulated taurine release from astroglial cells do not require extracellular calcium. J. Neurosci. Res. (in press).

Miller, R. J. (1987) Multiple calcium channels and neuronal function. Science 235: 46-52.

Newman, E. A. (1985) Voltage-dependent calcium and potassium channels in retinal glial cells. Nature 317: 809-811.

Perrone, M. H., R. D. Lepore, and W. Shain (1986) Identification and characterization of substance P receptors on LRM55 glial cells. J. Pharmacol. Exp. Ther. 238: 389-395.

Philibert, R. A., K. L. Rogers, A. J. Allen, and G. R. Dutton (1988) Dose-dependent, $\mathrm{K}^{+}$-stimulated efflux of endogenous taurine from primary astrocyte cultures is $\mathrm{Ca}^{2+}$-dependent. J. Neurochcm. $51: 122-$ 126.

Rink, T. J., S. W. Smith, and R. Y. Tsien (1982) Cytoplasmic free $\mathrm{Ca}^{\prime}$ ' in human platelets: $\mathrm{Ca}^{\prime}$ ' thresholds and $\mathrm{Ca}$-independent activation for shape-change and secretion. FEBS Lett. 148: 21-26.

Schwartz, E. A. (1987) Depolarization without calcium can release $\gamma$-aminobutyric acid from a retinal neuron. Science 238: 350-355.

Shain, W., and D. L. Martin (1984) Activation of $\beta$-adrenergic receptors stimulates taurine release from glial cells. Cell Mol. Neurobiol. 4: 191-196.

Shain, W., V. Madelian, D. L. Martin, H. Kimelberg, M. Perrone, and $R$. Lepore (1986) Activation of $\beta$-adrenergic receptors stimulates release of an inhibitory transmitter from astrocytes. J. Neurochem. 46: 1298-1303.

Shain, W., D. S. Forman, V. Madelian, and J. Turner (1987a) Morphology of astroglial cells is controlled by beta-adrenergic receptors J. Cell Biol. 105: 2307-2314.

Shain, W., V. Madelian, D. L. Martin, and S. Silliman (1987b) Ethanol stimulates protein phosphorylation and taurine release from astroglia cells. Ann. NY Acad. Sci. 492: 403-404.

Sugino, H., A. Ogura, Y. Kudo, and T. Amano (1984) Intracellular $\mathrm{Ca}^{++}$elevation induced by a neurotransmitter in a glial cell clone. Brain Res. 322: 127-130.

Tossman, U., T. Wieloch, and U. Ungerstedt (1985) $\gamma$-Aminobutyric acid and taurine release in the striatum of the rat during hypoglycemic coma, studied by microdialysis. Neurosci. Lett. 62: 231-235.

Tsien, R. Y., T. J. Rink, and M. Poenie (1985) Measurement of cytosolic free $\mathrm{Ca}$ in individual small cells using fluorescence microscopy with dual excitation wavelengths. Cell Calcium 6: 145-157.

Vogel, Z., A. J. Sytkowski, and M. W. Nirenberg (1972) Acetylcholine receptors of muscle grown in vitro. Proc. Natl. Acad. Sci. USA 69: 3180-3184.

Walz, W., and D. C. Wilson (1986) Calcium entry into cultured mouse astrocytes. Neurosci. Lett. 67: 301-306.

Waniewski, R. A., and D. L. Martin (1984) Characterization of L-glutamine and transport by glioma cells in culture: Evidence for sodiumindependent, chloride-dependent high affinity influx. J. Neurosci. 4 . 2237-2243

Williams, D. A., K. E. Fogarty, R. Y. Tsien, and F. S. Fay (1985) Calcium gradients in single smooth muscle cells revealed by the digital imaging microscope using fura-2. Nature 318: 558-561.

Wolpaw, E. W., and D. L. Martin (1984) $\mathrm{Cl}^{-}$transport in a glioma cell line: Evidence for two transport mechanisms. Brain Res. 297. 317-327. 